\title{
派生問題の自動生成機能の開発とその実験的評価 Development of Automatic Generation Function of Derivative Problems and Its Experimental Evalu- ation
}

\author{
大川内 祐介 \\ 広島大学大学院 工学研究科 \\ Yusuke Ookawachi Graduate School of Engineering, Hiroshima University \\ ookawachi@isl.hiroshima-u.ac.jp
}

上野 拓也
Takuya Ueno

平嶋 宗

Tsukasa Hirashima

\author{
(同上) \\ uenodisl.hiroshima-u.ac.jp
}

(同上)

tsukasalisl.hiroshima-u.ac.jp

Keywords: derivative problem, graph of microworlds, solution structure, special / general problem, partial / expansional problem

\section{Summary}

This paper describes a function of automatic problem generation of high school level mechanics problems for adaptive exercises. We have defined derivative problems from view point of specialization-generalization or partialization-expansion of solution structure of the original problem. In this framework, first, a problem is characterized by a situation model the problem belongs to and solution structure that describes the way to solve it. Specialization or generalization is applied for a situation model. Relation between situation models from view point of specialization or generalization are described as a microworld graph, and by following the connections, a problem can be specialized or generalized. Partialization or expansion is applied for solution structure. By partializing or expending solution structure of the original problem, partialized or expand problems are generated. We call these generated problems "derivative problems" for the original one. We have already implemented the automatic generation function of these derivative problems. Two experimental evaluations of the function and generated problems were carried out. This paper described the results of the experiments.

\section{1.はじめに}

問題演習は，様々な問題を解くことで学習した事項を 確認・定着させ, 問題解決能力を鍛える学習活動であり, 算数や数学，物理などの様々な分野で行われている. 問 題演習においては, 学習者は複数の問題を解くことを求 められるが，これには（1）同じ学習事項に対応する同 質の問題を繰り返し解くことが求められる場合と，（2） 複数の学習事項に渡る複数の質の異なる問題を解いてく ことを求められる場合, とがある. 後者の場合, 問題の 系列が学習上の意味を持っているのが一般的である[松 居 10]. 問題演習における問題系列の影響については, Scheiter らによって類推に基づく学習の転移という観点 から調査が行われており, 問題構造が徐々に複雑になっ ていくように設計された問題系列は, それらがランダム に並べられた場合よりも問題解決によい影響を与えるこ と, また, その効果を得る上で問題が系列化されている ことを学習者が認識することが重要であると報告してい る[Scheiter 02]. また, 適切な問題系列は学習対象に対
して一意に決定されるものではなく，個々の学習者の事 前知識や問題演習の進度, 理解度や問題解決履歴などに よって, 問題演習中にも動的に変化するものだと考えら れる[菅沼 05].これらのことを踏まえると, 効果的な問 題演習に必要な問題系列を設計するためには，まず，大 量の問題を用意した上で，様々な演習状況に対応できる ように, 網羅的に問題同士を関連付けておくことが必要 となる。

本研究では, 高校物理の力学を対象として, ある問題 の簡単化および複雑化を解法の観点から定義した上で, 簡単化と複雑化としての関係づけを伴った問題を自動生 成する仕組みを設計・開発し，実験的に評価した。解法 の観点からの簡単化された問題とは，元問題に対する解 法がその簡単化された問題に対する解法を含んでいるこ とである.また，複雑化された問題とは，その問題に対 する解法が，元問題の解法を含んでいることである.こ こでの含んでいるとは，（1）特殊・一般，の関係にある 場合と，（2）部分・全体の関係にある場合がある。本研 究ではこれらの関係を定義した上で, 自動生成機能を作 成した.これによって生成される問題を派生問題と呼び, 
それぞれの方法で生成される問題を，特殊化問題，一般 化問題, 部分化問題, 拡張化問題, と呼んでいる. 問題 間の関係は，その生成法として説明されることになる. 筆者らの目標は, 対象領域において用いられる問題を, その問題の特徵記述を伴って網羅的に用意することであ り，そのために問題の自動生成というアプローチをとっ ている.本研究では, ある問題に対する「特殊化・一般化」 および「部分化・拡張化」の関係にある問題の自動生成を 試みており, 問題の特徵記述は, 元の問題の特殊化・一般 化·部分化・拡張化として得ることができる. このように 生成される問題は, 後述の漸進的問題演習を網羅するも のとなるが，一般的な問題演習の範囲を直接的にカバー するものではない, したがって, 本研究は, 問題演習に おいて用いられる問題の網羅的な用意を目指寸という目 標の一部を実現したものとなっている. また, 学習者に 応じた出題を考えると, さらに学習者モデリングおよび 学習者モデルに基づいて問題を選択する出題機能の実現 が必要となる. 本研究によって生成される問題は, 元の 問題に対する関係が明らかになっている点で, 単なる問 題の列挙とは異なってはいるものの, 本論文で実現した 問題生成機能だけで問題演習を実現することができない ことも明らかである。したがって, より広い範囲の問題 演習への対応および本問題自動生成機能によって生成さ れる問題を用いた問題演習の実現は，今後実現してゆく べき課題となっている.

以下本稿では, 第 2 章で, 力学の問題の構造的表現に ついて述へ，第 3 章で派生問題の定義とその生成方法, および本問題生成が直接的に対象としている漸進的問題 演習について述べる. また, 第 4 章で, 本研究において 設計・開発を行った派生問題の自動生成機能を持つシス テムについて紹介し, 工学系大学生と高専教員を対象に 行った評価実験とその結果について報告する.

\section{2. 力学の問題の構造化}

本研究では, 力学の問題の中でも, ある物理状況下に おいて, ある属性值群が与えられた場合に, ある属性值 を求める計算問題を対象としている. 本章で述べる (1) 個々の問題の記述法, および (2) 問題が設定される物 理状況とそれらの物理状況間の関係の記述法, について は，これまで筆者らが行ってきた先行研究に基づくもの であり, ここには新規性はないものの, 本研究での問題 の自動生成を説明する上での基盤となるため，ここで説 明する。

\section{1. 力学の問題の定義}

先行研究において力学の問題を，(1) 問題文を表現す る表層構造，（2）問題文から定式化した構造を用いて解 を導く過程を表現する解法構造，（3）問題の背景となっ
ている物理状況を表現する制約構造の 3 つ構造を用いて, その特徵を記述する手法が提案されている[平嶋 95]. 本 研究では, これら 3 つの構造の中でも, 特に問題の解き 方に影響を与える解法構造及び制約構造に着目し, 力学 の問題を，問題の背景を表す『物理状況』と，与えられ た属性（入力属性）から求めるべき属性（出力属性）を 導出するまでの過程を表す『解法』の 2 つの特徽から構 成されると改めて定義を行った（図 1）[上野 09].

システムで力学の問題を取り扱うために, これら $2 つ$ の特徴を記述するための枠組みをモデル化しなければな らない. そこで, 本研究では, 『物理状況』をマイクロワ ールドグラフで,『解法』を解法構造で記述する方法を採 用している。 それぞれについて $2.2,2.3$ 節で説明する.

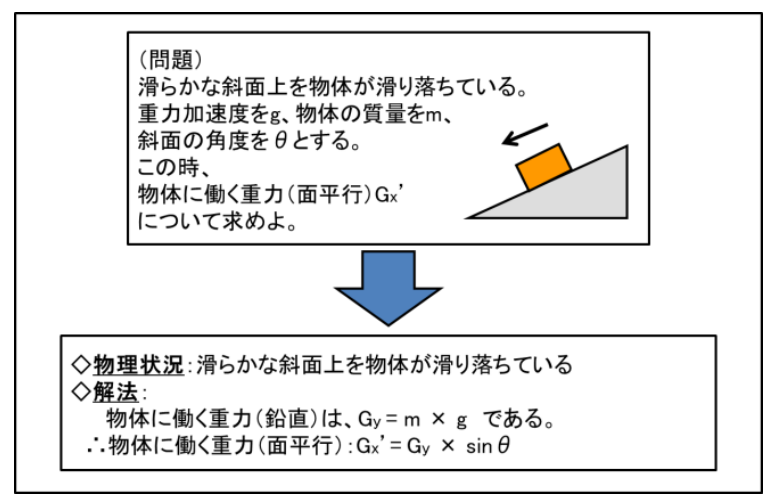

図 1 問題の定義例

\section{2. マイクロワールドグラフ}

堀口らは自動モデリングの手法[Addanki 91]を高校程 度の力学学習において取り扱われる種々の力学的状況に 適用することで，その状況に関するモデルの生成プロセ スに基づいて特徴づける枠組みを提案しており，これを マイクロワールドグラフと呼んでいる[Horiguchi 05, 東 本 08]. 力学的状況は, 基本となる属性と, その属性值 から值が決まってくる二次的な属性からなる. マイクロ ワールドグラフでは，力学的状況を規定している基本属 性およびその值（もしくは值の範囲）をモデル化仮定と 呼ぶ. そして，そのモデル化仮定によって成立する状況 において存在する様々な属性および属性間の制約関係を 表現したものがモデルとなる．モデル化仮定及びモデル の具体例を図 2 に示した.このモデル化仮定が変わると, 成立するモデルは変化することとなり，また，このモデ ル化仮定の変更可能性は, 物理法則に沿って規定される. たとえば, 摩擦係数は 0 が最も特殊であり, その一般化 は正の值をとり，負の值をとることはない，このような モデル化仮定の派生関係に基づいて力学的状況およびそ れら間の関係づけを記述したものがマイクロワールドグ ラフである. 現時点では, マイクロワールドグラフ自体 はその枠組みに従って人手で記述していく必要があるが, そのオーサリング支援および自動化に関しての研究も進 められている[Horiguchi 09].

本研究では，マイクロワールドグラフを問題間の差分 
を取り出すための基盤として使用するため，先行研究で 定義されたマイクロワールドグラフの記述手法に従った ものを用意した。実際のシステムで使用しているマイク ロワールドグラフは, 図 3 のように互いに関連した状況 同土が隣接したネットワークで構成されている. M1 M6 が物理状況であり，M3 と隣接しているのは M1,M5,M6 であり，M1 は特殊化，M5,M6 は一般化の 関係にある。また，それぞれの物理状況下におけるモデ ル化仮定及びモデルは，システム上では図 4 のように記 述されている. 開発したシステム上で使用しているマイ クロワールドグラフには現在 63 個の物理状況が用意さ れている.これらの物理状況が, 高校物理 IB の力学の 範囲で現れる力学的状況のうち, モーメント, 不連続な 運動の項目において現れるものを除いたものを網羅して いることを複数の教科書において事例的ではあるものの 確認している，また，残りの範囲についても今後実装す る予定である.



図 2 モデル化仮定とモデルの例

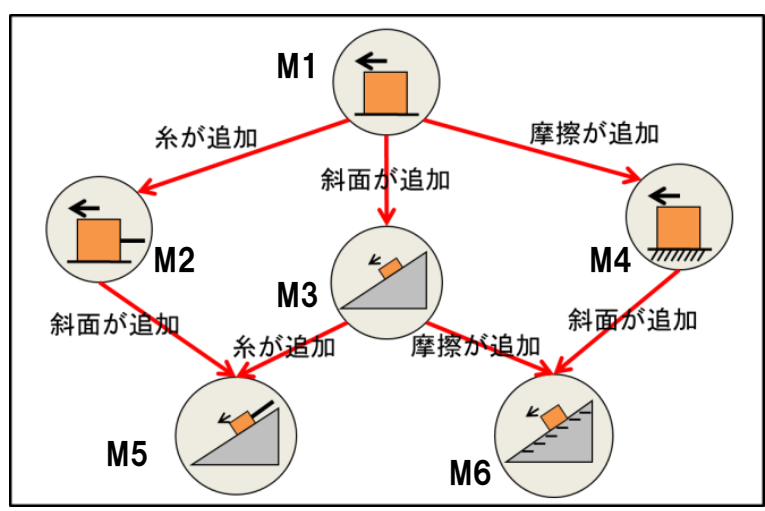

図 3 マイクロワールドグラフの例

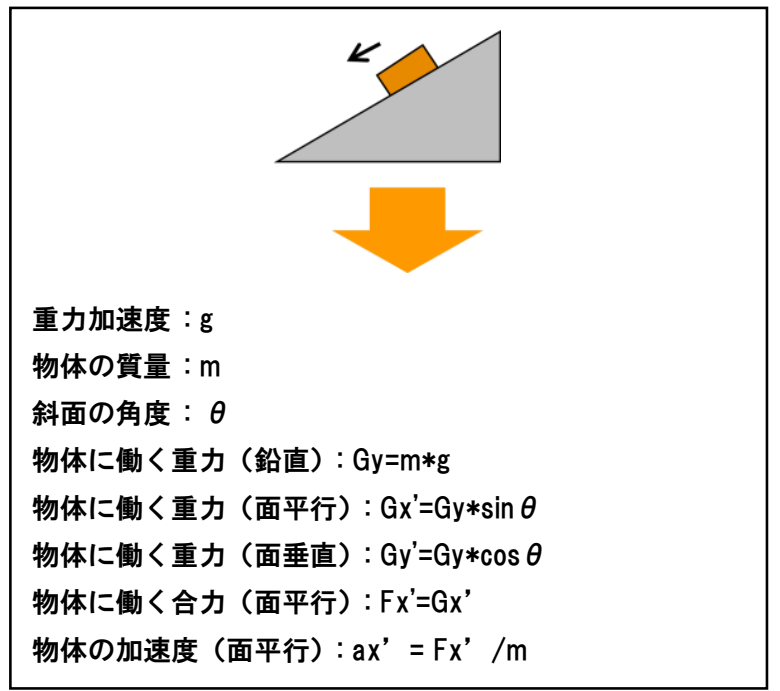

図 4 システム上での記述例

\section{3. 解法構造}

前節において，マイクロワールドグラフを用いること で，ある物理状況における数量関係を表現することが可 能となるということを述べた．しかしながら，力学の問 題の特徴を表現するためには，物理状況におけるどの数 量関係を用いて未知属性を求めたか，すなわち，どのよ うに問題に解答したかということを把握することも重要 な要素の 1 つである。

力学において未知量を求める問題の解導出過程は, 解 を導くために用いられる一連の数量関係で表現すること ができる．本研究では，このような一連の数量関係を解 法構造（図 5）と呼ばれる表現方法で記述している[平嶋 95].

解法構造は，入力属性ノード，中間属性ノード，出力 属性ノードとそれらをつなぐ式ノード及びエッジからな る. 入力属性は，問題において与えられている既知の属 性のことであり, 出力属性は, 問題の物理状況下におい て成り立つ数量関係を用いて, 入力属性より導出すべき 属性のことである. そして, 中間属性は, 入力属性から 出力属性を導くまでの数量関係において使用する属性の ことである。

開発したシステムでは，ユーザが物理状況を選択し， その後出力属性及び入力属性とする物理属性を図 4 に記 述されたデータの中から選択すると, 問題文及び解法構 造をマイクロワールドグラフの制約構造（モデル）から 自動生成する仕組みとなっている. 


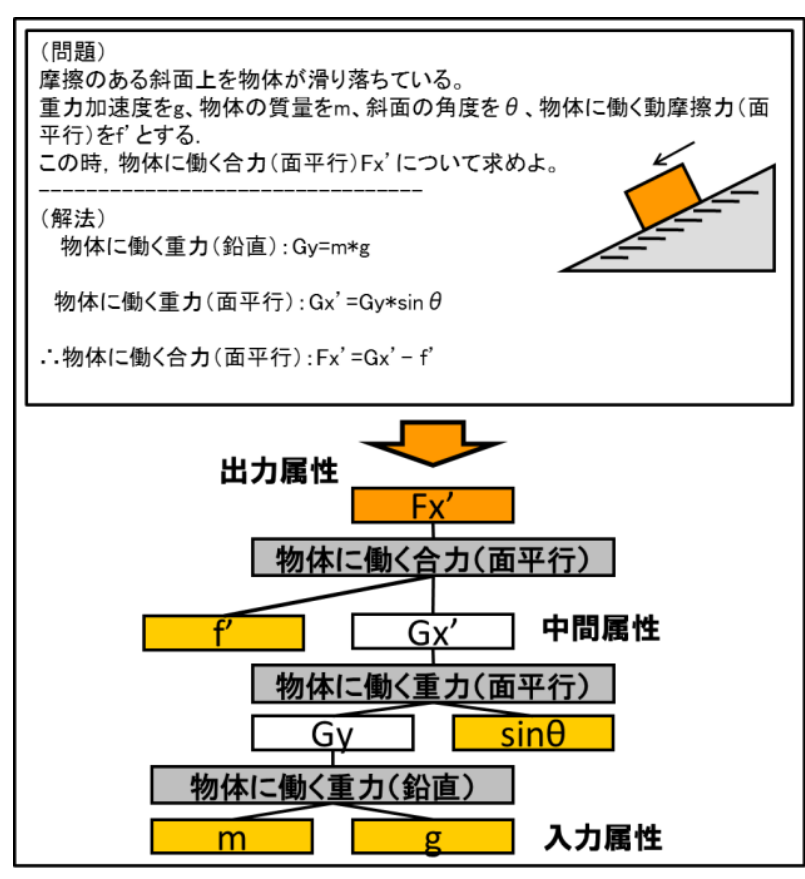

図 5 解法構造の例

\section{3. 派生問題}

本章では，本研究での問題生成の対象となる「派生問 題」について述べるとともに，派生問題を使うことで実 現できる漸進的問題演習について説明する.

\section{1. 派生問題}

ある任意の 2 つの力学の問題間の関係を, 物理状況と 解法の 2 つ観点から表 1 のような 4 つに整理すること ができる。ここで「包含」とは，物理状況においては， 特殊・一般の関係にあることであり, 解法においては, 部 分・全体の関係にあることである.物理状況において特殊 であるとは，あるパラメータがその值を考慮しない計算 を行ってよい值に特殊化されていることであり（たとえ ば，初速度を０としたり，動摩擦係数を０としたりする こと), また，一般的であるとはそれらの值を考慮した計 算が必要な值に設定されていることである．前章で述べ たマイクロワールドグラフのエッジは，物理状況間の一 般・特殊関係を表している.解法における部分であるとは, ある解法の構造の一部となっていることであり，全体と は，その一部を完全に含んでいることである。この全体・ 部分関係は解法構造における包含関係として表すことが できる。

状況包含解法非包含問題とは，ある問題に対して，対 象としている物理状況は包含関係にあるものの，解法に 関しては包含関係にない問題である. 解法包含状況非包 含問題は, ある問題に対して, 解法に関しては包含関係 にあるものの，物理状況に関しては包含関係にない問題 である．物理状況および解法において包含関係にある問
題は，状況包含解法包含問題となり，これを本研究では 派生問題を呼び，生成の対象としている.

派生問題において一般・特殊関係にある場合，特殊な 問題では対応する一般的な問題で問われている同様なこ とがより特殊な状況で問われていることなり，一般的な 問題の問題解決過程をその特殊なパラメータで特殊化す ることでその特殊な問題の解決過程に変換できることか ら，ある特殊な問題の問題解決過程は，対応する一般的 な問題の問題解決過程に包含されているということがで きる．全体・部分関係にある問題の場合には，それらは 同じ物理状況において設定されている問題であり，その 部分に相当する問題の問題解決過程は, 全体に相当する 問題の問題解決過程に直接的に包含されることになる. [平嶋 95] で報告されている力学の問題集の調査では, ある問題の解決を補助するものとして位置づけられてい る問題の $72 \%$ この派生問題に属するものとなってい ることから，この種の問題を生成の対象とする意義は大 きいと判断している.

以下本章では，この派生問題についてより詳細に述心゙ るとともに，この派生問題を用いて実施される漸進的問 題演習について述べる.

表 1 問題間の関係の分類

\begin{tabular}{|c|c|c|c|}
\hline & & \multicolumn{2}{|c|}{ 物理状況 } \\
\hline & & 包含している & 包含していない \\
\hline \multirow{2}{*}{$\begin{array}{l}\text { 解 } \\
\text { 法 }\end{array}$} & 包含している & 派生問題 & $\begin{array}{c}\text { 状況非包含 } \\
\text { 解法包含問題 } \\
\end{array}$ \\
\hline & 包含していない & $\begin{array}{c}\text { 状況包含 } \\
\text { 解法非包含問題 }\end{array}$ & 非包含問題 \\
\hline
\end{tabular}

\section{2. 派生問題の分類と生成法}

\section{§1 状況に基づく派生問題}

状況に基づく派生問題としては，特殊化問題と一般化 問題の 2 つを定義することができる．これら対応する 2 つの派生問題はたとえば図 6 のような対応関係を持つ. 図 6 左のように, 摩擦のある斜面に関する問題において 摩擦係数を 0 とすると, 摩擦が 0 の時にの夕利用可能な 解法が適用される図 6 右の問題が得られる。図 6 左の問 題は摩擦を持った様々な問題に対応しており，また，図 6 右の問題は, 摩擦を持たない問題にの夕対応している. このことから, 本研究では, 図 6 左をより一般的な問題, 図 6 右をより特殊な問題としている。そして, 図 6 左か ら図 6 右を作り出すことを問題の特殊化と呼び，作られ た問題を特殊化問題と呼ぶ。逆に，図 6 右から図 6 左を 作り出すことを問題の一般化と呼び，作られた問題を一 般化問題と呼ぶ。 ある学習者が，ある問題が解けず，そ の特殊化問題が解けた場合には，その問題が解けなかっ た原因は，特殊化問題と元問題の差分にあると特定でき る.また，ある問題を解いたうえでその一般化問題に取 り組む場合は, 学習者が克服すべきはその元問題と一般 
化問題の差分であると特定することができる.

特殊化・一般化には, 図 3 のようなマイクロワール ドグラフ上での物理状況（マイクロワールド）の隣接関 係を用いる．特殊化問題の場合は，マイクロワールドグ ラフに基づき, 現在の問題の物理状況に隣接している, 一般化された物理状況を一つシステムが選択し，その状 況での特殊化問題の生成が試みられる. その隣接した物 理状況と, 現在の物理状況間において, 特殊化される属 性，およびその属性によって影響を受ける数量関係につ いては，モデル化仮定としてマイクロワールドグラフに 記述されているので，それを用いて現在の問題の解法構 造にその特殊化される属性が含まれていた場合，その物 理状況において元の問題は特殊化され得ると判定する. 特殊化でさると判定した場合, その特殊化された属性お よび数量関係を用いて元の問題の解法構造を修正する.

図 6 左の場合であれば，動摩擦力が 0 となり省略される ことがわかるので, 結果として特殊化問題の解法構造は 図 6 右のようなものとなり, これによって出力属性およ び入力属性が決まり, 特殊化問題が生成される。もしそ の物理状況において解法構造が特殊化されない場合には, その物理状況においての特殊化問題の生成は行えないと 判定する. 一つの隣接する物理状況において生成できる 特殊化問題は一つであるので, その物理状況において特 殊化問題が生成できた，もしくは生成できなかった場合 には，別の隣接する物理状況を対象として，その物理状 況で特殊化問題の生成を試みる. 対象となる隣接する物 理状況がなくなれば，特殊化問題の生成は終了する.

一般化問題の場合も同様に，マイクロワールドグラフ に基づき, 現在の問題の物理状況に隣接した, 一般化さ れた物理状況をシステムが一つ選択し, その物理状況で の一般化問題の生成を試みる. その隣接した物理状況と, 現在の物理状況間において一般化されている属性, およ びその属性によって影響を受ける数量関係については, モデル化仮定としてマイクロワールドグラフに記述され ている. 現在の問題の解法構造にその一般化の対象とな っている属性が含まれていた場合, その属性の值を入力 属性に加えて, 改めて一般化された物理状況において解 法構造を作成する。図 6 右の場合であれば,「摩擦力」 が存在する物理状況においては,「物体に働く合力（斜面 平行)」は摩擦力との合力となる. したがって, 解法構造 において「摩擦力」の追加が行われることになる。この 結果として, 入力属性として摩擦力が追加された解法構 造が生成され，これにより「摩擦力」を入力属性として 含んだ一般化問題が生成されることになる. 一般化問題 が生成できない場合には，次の物理状況を取り上げて，

一般化問題の生成を試みる. 特殊化問題と同様, 一般化 問題も一つの物理状況において高々 1 問しか生成できな い. 隣接する物理状況がなくなると, 一般化問題の生成 を終了する.

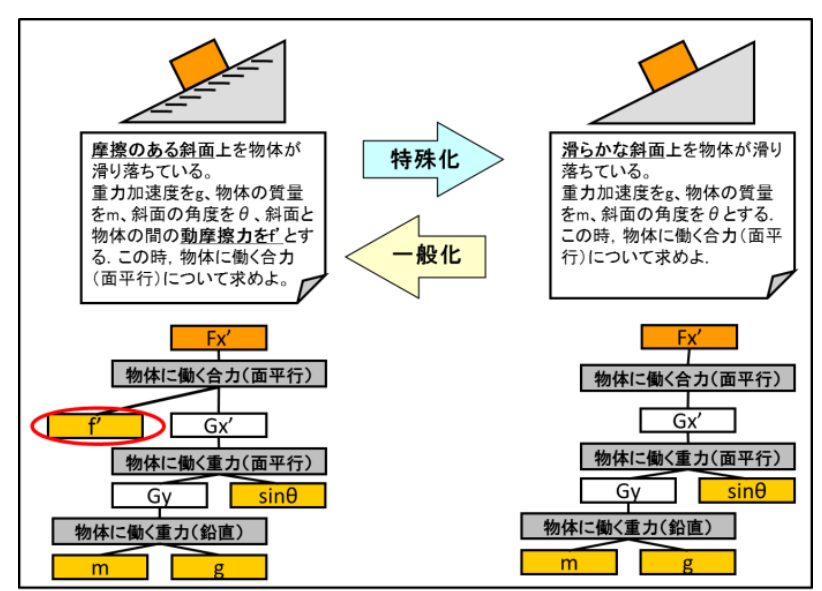

図 6 特殊化問題と一般化問題

\section{§2 解法に基づく派生問題}

解法に基づく派生問題としては, 部分化問題と拡張化 問題の 2 つを定義することができる．まず，部分化問題 とは, 図 7 のように, 元の問題の解法構造の部分を解法 構造として持つ問題である. この部分化は, 元の解法構 造中の中間属性を出力属性, もしくは入力属性とするこ とで生成できる。たとえば，図 7 の場合であれば，左の 解法構造中の中間属性である Gy : 物体に働く重力の鉛 直方向成分，を入力属性として「物体に働く重力の鉛直 方向成分」を值として与えることにすると，質量と重力 加速度からその值を求める部分が省略された部分化問題 が生成される。

拡張化問題は, 図 8 のように, 元の問題の出力属性を 中間属性として別の属性を出力する解法構造を持つ問題 と, 図 9 のように, 元の問題の入力属性を中間属性とし て別の入力属性から求めるようになっている問題，の二 種類がある. 本研究で用いているマイクロワールドグラ フ中の各物理状況は, その物理状況において存在する属 性と属性間の数量関係を持っており, 解法構造はその数 量関係の一部を用いて入力属性の組から出力属性を求め る計算手順を示していることになる.

ある学習者が元問題を解けず，その部分化問題を解け た場合は，学習者が元問題を解けなかった原因は，それ らの問題の差分に存在することなる，また，ある問題を 解けた学習者に拡張化問題を与える場合, 学習者が新た に取り組むのは，それらの問題の差分であるということ になる。

部分化問題の生成は, 解法構造を対象として, その中 間属性を入力属性もしくは出力属性とすることで問題の 生成を試みる。まずは中間属性の入力属性化を試み, 1 つの中間属性を入力属性として場合に，他の入力属性お よび出力属性から解法構造の部分が抽出できるかを試み る. 部分構造が抽出できば，その部分構造に関係する入 力属性と出力属性からなる部分問題が生成されたことと なる。これを全ての中間属性に対して行う。一つの場合 
が終了すれば, 複数の中間属性の組に対しても同様の入 力属性化による部分化問題生成の試みを行う。すべての 場合を尽くすと, 中間属性の入力属性化による部分化問 題の生成を終了する. 中間属性の出力属性化の場合は, 中間属性を一つ出力属性と設定し, その出力属性を入力 属性から生成する部分構造を抽出することで, 部分化問 題を生成する. 中間属性は解決過程で求められるもので あるので，ある中間属性を出力属性化すると，必ず一つ の部分化問題を得ることができる．ここでさらに，ある 中間属性を出力属性化して得られた部分化問題を対象に, その部分化問題に含まれている中間属性を対象とした入 力属性化による部分化問題の生成も試みる. これらを尽 くすことで, 部分化問題の生成が終了する.

拡張化問題の生成の場合, 問題が設定されている物理 状況に存在するすべての数量関係が拡張の対象となる. これをすべて対象とするのはあまりにも膨大であり，ま た, 元の問題から大きく離れた問題が得られる可能性が ある. そこで拡張化問題の生成においては, 中間属性化 した属性を求めるための式（式ノード）を一つに制限し ている. 出力属性を中間属性する場合, その出力属性を 用いている式を物理状況に用意されている制約構造から 見つけ，その式を構成する属性を追加する入力および出 力属性の候補となる（ただし，その属性が元の問題の解 法構造において現れる属性になっていた場合には，候補 としない). 取り上げた式が出力属性以外に三つの属性を 含んでいる場合, その三つの属性で一つの出力属性と二 つの入力属性を設定することとなり, 計三つの拡張化問 題が生成されることとなる. その出力属性を構成要素と する式すべてに対して拡張化問題の生成を行う. 入力属 性を中間属性とする場合も同様に, その入力属性を構成 要素とする式を制約構造中から見つけ，その式を構成す る他の要素を入力属性として設定した拡張化問題を生成 する. ある入力属性に関してすべての式について同様の ことを行った後, 別の入力属性を対象とする. すべての 入力属性に対して入力属性の中間属性化による拡張化問 題の生成を尽くして, 拡張化問題の生成は終了する.

\section{§ 3 派生問題生成システムの構成}

以上で述べた派生問題を生成するシステムの構成図 を図 10 に示した. ある問題の情報をシステムに入力す ると, その問題に対する一般化問題, 特殊化問題, 部分 化問題, および拡張化問題がそれぞれ独立に生成される. 一般化問題と特殊化問題は, マイクロワールドグラフの 一般特殊関係と物理状況の制約構造を参照した生成を行 う. 拡張化問題は, マイクワールドグラフの制約構造を 利用する. 部分化問題については, 解法構造の部分化と なるので, 元の問題の持つ情報から生成することかでき る. 生成された問題に対しては, 元の問題と同様の情報 とともに，その生成過程に関する情報を取り出すことが できる.この情報は元の問題と派生問題の差分を説明す
るものとして活用の可能性を持っているが, 現時点では, 派生問題の種類としてのみの利用となっており，この活 用は今後の課題である.

\section{3. 漸進的問題演習}

マイクロワールドを用いた学習においては，まずは簡 単なマイクロワールドで学習し, そのマイクロワールド を漸進的に複雑化してゆくことで, より複雑なマイクロ ワールドでの学習を達成するのが有効とされている [Burton 84]. 問題演習においても, 一連の問題を解決す る場合, 前に解いた問題の解き方が次の問題の解き方に 貢献する場合の方が，問題間に関係の無い場合よりも学 習効果が得られやすいことが知られている [Sheiter 02]. 漸進的問題演習は，これらの知見を踏まえた問題演習の 一つの形式であり，ある問題が解けた場合，その問題を 少し複雑化した問題を与え，また問題が解けない場合に は, その問題を少し簡単化した問題を与えるものである. この少し複雑化および少し簡単化を派生問題として行う。 ある問題を複雑化（つまり特殊化もしくは拡張化）した 問題は，大部分は元の問題と同じであり，その部分はす でに学習者にとって解決済みといえるので, 複雑化の部 分だけが元の問題と異なっていることとなり，学習者が 新たに乗り越えるべきはその部分だけとなる．ある問題 を簡単化（つまり一般化もしくは部分化）した問題は, その問題解決過程が元の問題の問題解決過程に包含され ることとなり, 必ず簡単になっているということができ る.もし簡単化した問題が解けた場合には, 元の問題と 簡単化した問題の差分が学習者にとって乗り越えるべき こととなる.

このような問題演習を実現するためには, 個々の問題 に対してその複雑化および簡単化の関係にある問題を網 羅的に用意することが必要となる. しかしながらこの用 意を行うためには, 数多くの問題を用意する作業に大き なコストを必要とするだけでなく, 問題間に適切な関係 付けを行っていく作業は問題数に対して級数的に増えて いくことになる．このことから，本研究では自動生成を 試みている. 問題間の関係はどのような簡単化・複雑化と して生成したか自体で説明されることとなる. 




図 7 部分化問題

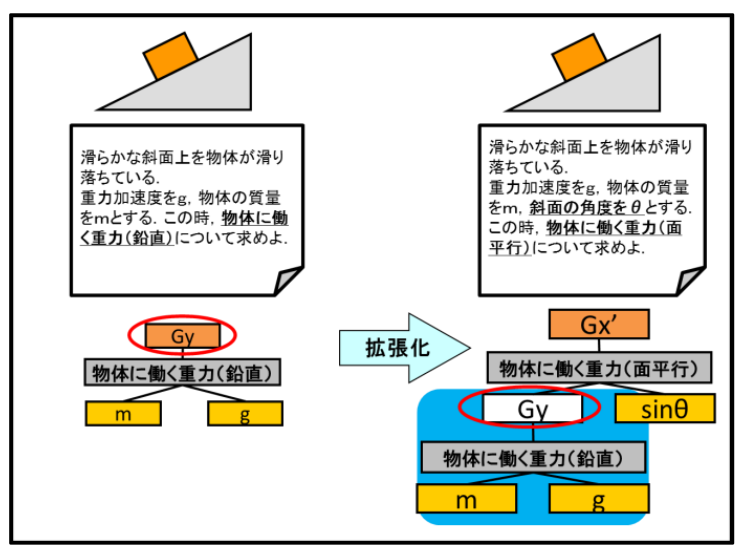

図 8 出力属性の拡張化問題

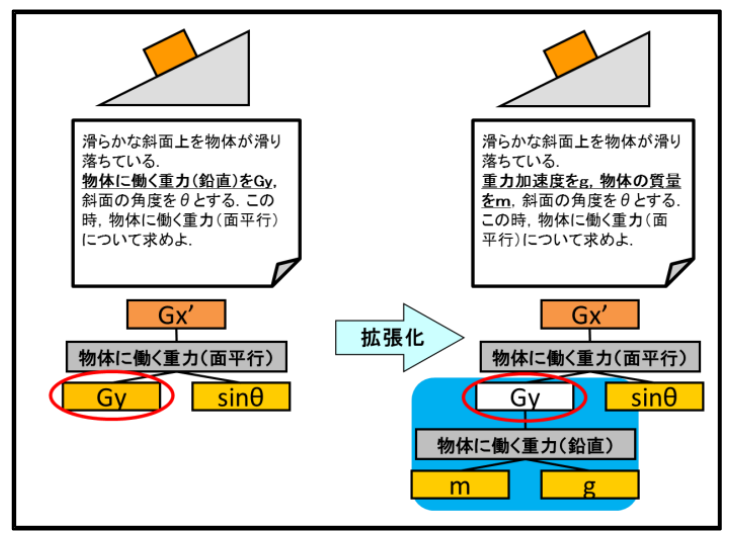

図 9 入力属性の拡張化問題

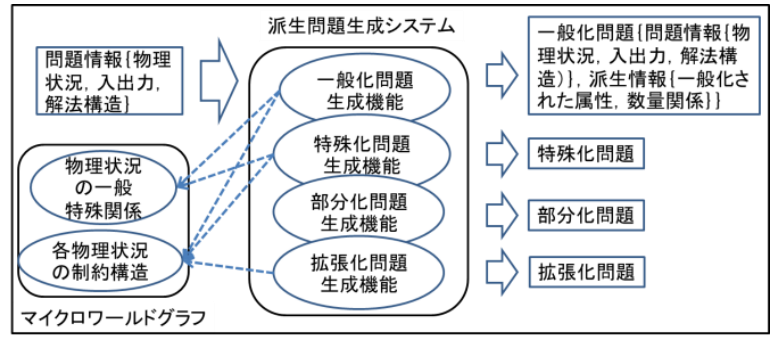

図 10 派生問題生成システムの構成

\section{4. プロトタイプの作成と評価実験}

\section{1. 実装と機能確認}

前章で紹介した 4 種類の派生問題を生成するシステム の実装を行った（図 11）。システムでは，例えば図 5 の 問題をもとにすると, 合計 49 問 (特殊化: 1 問, 一般化 : 2 問, 部分化 : 5 問, 拡張化: 40 問）の派生問題を生成 寸ることが可能である。 ここで, 特殊問題が 1 問および 一般化問題が 2 問であることは，この問題が属するマク ロワールドに隣接するより特殊な物理状況が 1 個, より 一般的な物理状況が 2 個であったことに由来する. 部分 化 5 問は，この解法構造が 5 つに部分化できることを示 している. 拡張化問題は，この物理状況に含まれている 他の様々な数量関係を用いることが許されているので, 数が多くなっている.

以下本章では，本システムで生成される派生問題が漸 進的問題演習において有用なものとなっているかどうか を確認する実験を行ったので報告する。

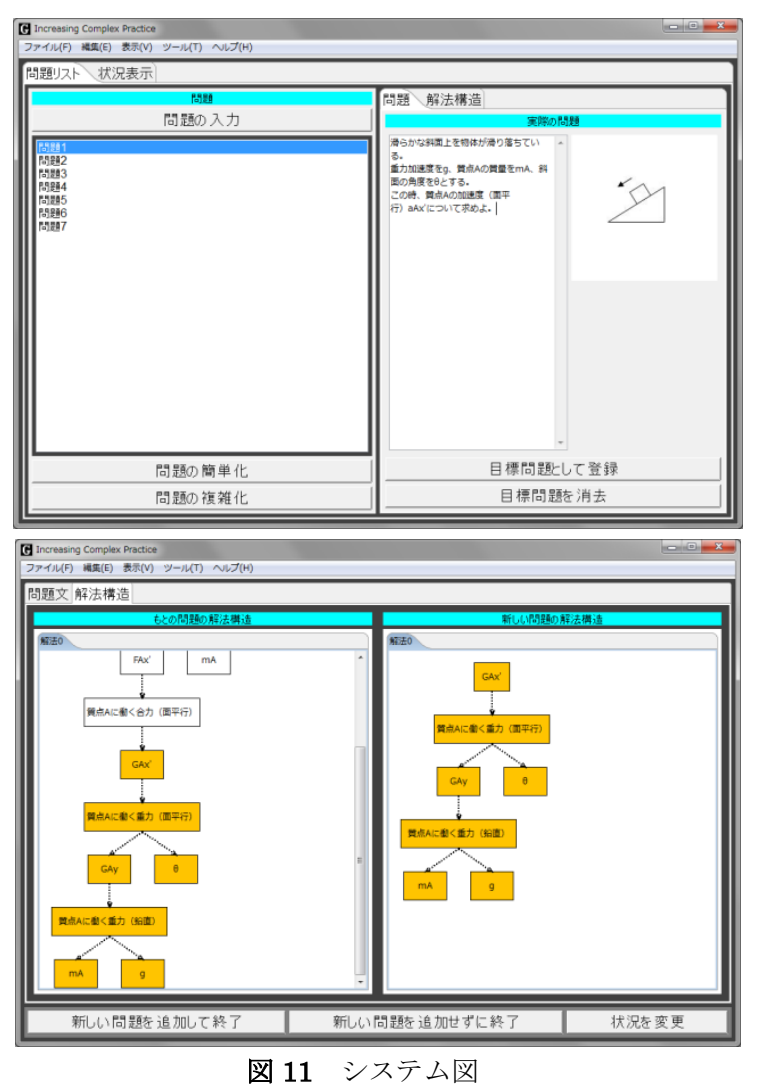

\section{2. 工学系大学生による派生問題作成実験}

\section{被験者}

本学の工学系の大学生・大学院生 13 名. 全員が大学 受験時の科目として物理を選択しており, 大学において も「物理学」の講義を 6 単位以上履修している. また, 全員が力学は得意であると自己評価をしている. 


\section{実験手順}

まず被験者に対して, 漸進的問題演習と派生問題およ びシステムを用いたその生成法について約 30 分事前説 明を行い，口頭で概ね合意が得られたことを確認したう えで, 4 種類の派生問題をそれぞれ別個に評価してもら った. ここで行った事前説明により，アンケート結果に 対してバイアスがかかる可能性があるが，漸進的問題演 習およびそのために用いられる派生問題の存在は自明と はいえないことから,「生成される問題が漸進的問題演習 に有用であるか」および「必要な問題が生成されている か」といった判断を被験者に行ってもらうに当たって, これらの説明は不可欠であると考えた。また，それらに ついて理解した上であれば判断が大きく変わることはな いであろうことから，この説明を行ったことは妥当であ ると考えている.

特殊化問題については,（1）まず予めある問題を元問 題として設定しておき, 被験者に特殊化ボタンを押させ ることで, 複数の特殊化問題をシステムが生成する. そ して，生成された特殊化問題のそれぞれについて，質問 項目(2)「生成した特殊化問題は, 元の問題を簡単化した ものとして適当だと思うか?」および質問項目(3)「元の 問題を解くことが出来ない学習者に対して, 生成した特 殊化問題を解かせることはヒントになると思うか?」に ついての回答を求めた.（2）次に, 生成された特殊化問 題のうちから一つを被験者に選ばせ，（1）と同様のこと を行った. 特殊化を 3 回行い, 計 7 問の特殊化問題を生 成し, それぞれについて質問項目 2 および 3 の回答を得 た. この作業を 15 分で行った. なお, 特殊化問題とし て他に有用なものがあれば自由記述欄にメモするように 指示した。この指示は他の派生問題に関しても同様であ る.

一般化問題についても特殊化問題と同様に元問題を設 定した上で, 一般化問題の生成, 元問題の再設定, を行 い, 2 回の一般化によって計 4 問の一般化問題を生成し た. 生成された一般化問題の個々に対して, 質問項目 (4) 「生成した一般化問題は, 元の問題を複雑化したものと して適当だと思うか? 」および質問項目 (5)「元の問題を 解くことができた学習者に対して, 生成した一般化問題 を解かせることは有効だと思うか?」についての回答を 求めた。

部分化問題と拡張化問題に関しては，元となる問題を システム上に二つ用意し, その解法構造およびその解法 構造を含んだ拡張化の対象となる数量関係を示し, 被験 者に入出力属性を設定させることで問題生成を行う方式 をとっている. 部分化問題については, 10 分間で平均 5 問が生成された。これらの問題に対して質問項目(6)「あ なたが作った部分化問題は, 元となった問題を簡単にし た問題だと思うか?」および質問項目 (7)「元の問題を解 くことが出来ない学習者に対して, あなたが作った部分 化問題を解かせることはヒントになると思うか?」につ
いての回答を求めた。部分化問題においては被験者に問 題の生成のための設定まで行わせており，作業負荷が大 きいと考えたので，この質問項目は作成した部分化問題 全体に対してのものとした.

拡張化問題については, 10 分間で平均 4 問が生成され た.これらの問題に対して質問項目(8)「あなたが作った 拡張化問題は, 元となった問題を複雑にした問題だと思 うか?」および質問項目 (9)「元の問題を解くことができ た学習者に対して, あなたが作った拡張化問題を解かせ ることは，演習を進める上で有効だと思うか?」につい ての回答を求めた．拡張化問題においても被験者に問題 の生成のための設定まで行わせており，作業負荷が大き いと考えたので，この質問項目は作成した拡張化問題全 体に対してのものとした.

問題に関する評価作業の終了後，質問項目(1)「漸進的 問題演習は効果的な演習方法だと思うか? 」(これは実験 の初めに口頭で確認した事項の確認としての質問項目で ある）および質問項目(10)「システムを使うことで，力 学の理解が変わったか?」の回答を求めた。 また, シス テムが生成するもの以外に生成すべき問題が存在すると すれば，それをメモするように促したにも関わらず，そ のような記述が見られなかったことから, 口頭で,「シス テムが生成した以外の有用な派生問題を思いついたか」 に関して，はい/いいえの形式で回答するように依頼し た.

\section{実験結果}

アンケートの結果を図 12 に示す。結果から，被験者 らは本研究が提案する派生問題の使用方法について概ね 同意しており，実際にシステムが生成した派生問題が元 の問題を適当に簡単・複雑化していると考えていること が分かった。 また，被験者全員がシステムの提示した派 生問題以外に有用な派生問題は思いつかないと回答した ことから, システムが概ね必要となる問題を生成できて いることが示唆された. 質問事項(3),(7)が他の質問と比 較して否定的意見が多く見られるが，この理由を自由記 述闌にて調査したところ, 否定的な回答をした全ての被 験者が，生成した問題がヒントになるかどうかはそれを 解く学習者に依存すると考えていたことが分かった．本 研究の現時点での目標である派生問題の自動生成という 観点からはこれは否定的な意見ではなく, 次の課題とな っている学習者に応じた問題の選択の必要性を指摘する ものと解釈できる．また，質問項目 (10)の結果は本シス テムの妥当性を直接的に支持するものではないが，派生 問題について考える作業を意味あるものとして被験者が 捉えていることを示しており，これは間接的に本研究の アプローチの妥当性を示唆するものと判断している. 本実験により，本システムが漸進的問題演習を支援する のに適した派生問題を生成できていることが確認できた， この結果を受けて教員らによる評価実験を行ったのでそ の方法と結果を次節で報告する. 


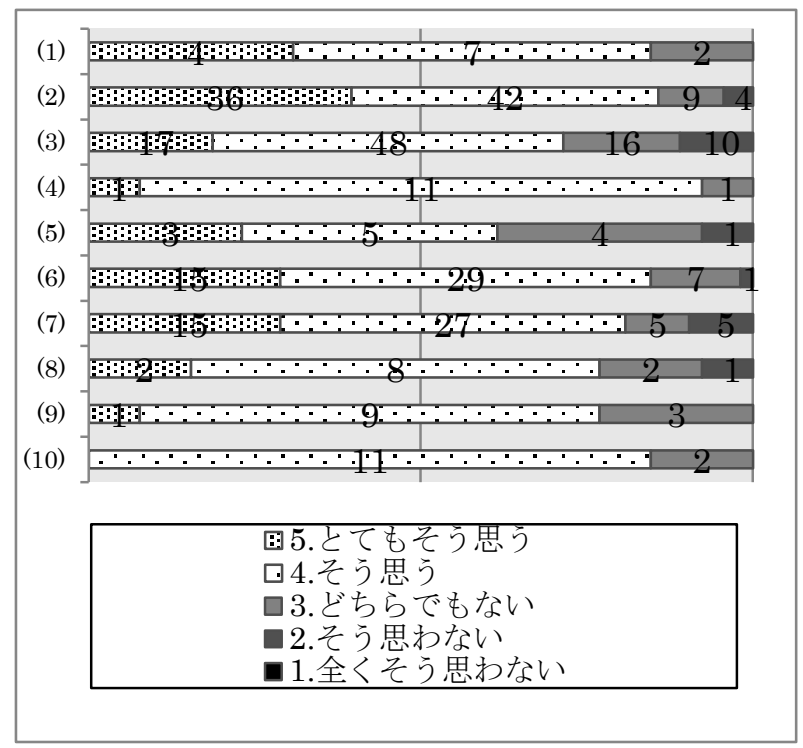

図 12 学生実験のアンケート結果

\section{3. 高専教員による評価実験}

本実験は，教授者の立場から見て，漸進的問題演習が 効果的な演習方法であるか及び，本システムが生成する 派生問題が，実際に漸進的問題演習を行うことを想定し た場合に有効であるかをアンケート形式で検証するもの である。

\section{被験者}

高専の教員 3 名（教養理科担当 1 名，物理専門担当 1 名, 情報系専門担当 1 名).

\section{実験手順}

システム開発者が漸進的問題演習及び派生問題の生 成方法について約 20 分事前説明を行った後, 実際に教 員らにシステムを使って 4 つの派生問題を 2 問ずつ生成 してもらい (約 20 分), その後でアンケートに回答して もらうという手順である。また，前回の実験と同様に， 追加すべき派生問題があれば，それを記述するように依 頼した．本実験は実験時間の都合上，前節での評価実験 のように多くの派生問題を生成して各問題を評価すると いうことはできなかったため, 派生問題を生成する手順 の確認や，派生問題ともとの問題との比較を行うことな どを主な目的としてシステムをしてもらったこととなる アンケート内容を表 2 に示す. アンケートの回答は, 学 生による実験と同様，「5. とてもそう思う」から「1. 全くそう思わない」までの 5 段階評価を採用した．質問 項目 (a), (b), (c)が漸進的問題演習に関する質問項目であ り, 質問項目 (d),(f)がシステムの生成する派生問題に対 する質問項目, 質問項目 (e), (g)が派生問題の使用方法に 対する質問項目である.

\section{実験結果}

アンケートの結果を表 3 に示す. 質問項目 (a), (b)の結 果から, まず被験者らが, 漸進的問題演習を効果的な演 習方法だと感じ, また, それを生徒に行わせたいと考え
ていることが分かった。しかしながら，実際に生徒に漸 進的問題演習のような演習を行わせたことがある教員は 1 名のみであり, それも個人指導の中で行ったもので, 一斉授業内で実際に行うことは難しいとのコメントを得 ている．また，質問項目 (c)により，システムが漸進的問 題演習を行う上で使用するのに適した問題を生成してい ることが分かった. 質問項目 $(\mathrm{d}) \sim(\mathrm{g})$ の結果により, 教授 者の立場から見ても, 問題の簡単化・複雑化の手段とし て，4 つの派生問題が適当であり，問題演習の支援に使 用するのに十分であるということが確認できた. これら の質問で，「3.どちらでもない」と回答した教員にその理 由を聞いたところ,「簡単化・複雑化がされたかどうかは, その問題を解く生徒によって異なると考えられるため, 問題だけではどちらとも言えない」という，学生を対象 とした実験で得られた意見と同じものだった。システム が生成したもの以外に有用な派生問題を思いついたかど うかについては, どの教員にも追加できる問題の記述が なかったことから，口頭で回答を依頼したところ，少な くともこの実験時間内では思いつかなかったとの回答で あった。

質問項目(h)では，全員が「3.どちらでもない」と回答 している.この理由として挙げられたものは, 出題する 問題の選択機能の必要性, 数值表記への対応や, 問題表 記をより実際の教科書や問題集にある問題文に近いもの にして欲しいといったもの，ユーザインタフェースの改 良などであった。現在これらの教育現場からの要望に対 応するシステムを開発中であり，同じ現場において試験 的な利用の試みもすでに行っている[武智 12]. この結果 等については, 研究をさらに発展させたうえで, 別途報 告する予定である.

表 2 教員実験のアンケート内容

\begin{tabular}{|c|c|}
\hline 質問項目 & 質問内容 \\
\hline (a) & 漸進的問題演習は効果的な演習方法だと思うか? \\
\hline (b) & 漸進的問題演習を生徒に行わせたいと思うか？ \\
\hline (c) & $\begin{array}{l}\text { システムが生成した問題は, 漸進的問題演習に使え } \\
\text { るものだったか? }\end{array}$ \\
\hline (d) & $\begin{array}{l}\text { 簡単化（特殊化・部分化）は，問題を簡単にしてい } \\
\text { ると思うか? }\end{array}$ \\
\hline (e) & $\begin{array}{l}\text { 簡単化した問題を解かせることは, 簡単化前の問題 } \\
\text { を解くことが出来ない学習者に対してヒントにな } \\
\text { ると思うか? }\end{array}$ \\
\hline (f) & $\begin{array}{l}\text { 複雑化 (一般化・拡張化) は, 問題を複雑にしてい } \\
\text { ると思うか? }\end{array}$ \\
\hline (g) & $\begin{array}{l}\text { 複雑化した問題は, 複雑化前の問題を正解した生徒 } \\
\text { に解かせる問題として適切だと思うか? }\end{array}$ \\
\hline (h) & $\begin{array}{l}\text { このシステムを使うことで, 力学の問題生成が楽に } \\
\text { なると思うか? }\end{array}$ \\
\hline
\end{tabular}


表 3 教員実験のアンケート結果

\begin{tabular}{|c|r|r|r|r|r|}
\hline & 5. & 4. & 3. & 2. & 1. \\
\hline (a) & 0 & 3 & 0 & 0 & 0 \\
\hline (b) & 1 & 2 & 0 & 0 & 0 \\
\hline (c) & 0 & 3 & 0 & 0 & 0 \\
\hline (d) & 0 & 2 & 1 & 0 & 0 \\
\hline (e) & 0 & 2 & 1 & 0 & 0 \\
\hline (f) & 0 & 2 & 1 & 0 & 0 \\
\hline (g) & 0 & 3 & 0 & 0 & 0 \\
\hline (h) & 0 & 0 & 3 & 0 & 0 \\
\hline
\end{tabular}

※5.とてもそう思う4.そう思う 3.どちらでもない 2. そう思わない 1.全くそう思わない

\section{5. まとめ}

本稿では，高校物理の力学における問題演習の高度化 を目指して，物理状況と解法までを含んだ問題の構造を 定義し, さらに, それらを用いて, 問題の構造を変化さ せることによる派生問題の生成手法を提案し，その自動 生成を行うシステムの設計・開発を行った。システムの 実験的評価を通して，本手法によって生成された派生問 題が問題演習に利用する上で有用であることが示唆され た.

今後は，システムに改良を加え，生成された問題を用 いた問題演習を教育現場において実践することを目指す。 また，本実験を通して示唆された派生問題の生成活動に よる学習効果なども検証していく予定である。

\section{$\diamond$ 参考文献 $\diamond$}

[Addanki 91] Addanki, S., Cremonini, R., Penberthy, J.S.: Graphs of Models, Artificial Intelligence, 51, pp.145-177 (1991).

[Burton 1984] Burton, R.R., Brown, J.S. \& Fischer, G.: Skiing as a model of instruction, In Rogoff, B. \& Lave, J. (Eds.),Everyday Cognition: its development in social context, Harvard Univ.Press (1984).

[平嶋 95] 平嶋 宗, 東 正造, 柏原昭博, 豊田 純一: “補助 問題の定式化”, 人工知能学会誌, Vol.10, No.3, pp.413-420(1995).

[Horiguchi 05] Tomoya Horiguchi, Tsukasa Hirashima: Graph of Microworld : A Framework for Assisting Progressive Knowledge Acquisition in Simulation-based Learning Environments. The 12th International Conference on Artificial Intelligence in Education, pp.670-677(2005) .

[Horiguchi 09] Tomoya Horiguchi, Tsukasa Hirashima,: Intelligent Authoring of 'Graph of Microworlds' for Adaptive Learning with Microworlds based on Compositional Modeling. The 14th International Conference on Artificial Intelligence in Education, pp.207-214(2009).
[松居 10] 松居 辰則, 平嶋 宗: ”学習課題・問題系列のデザ イン”, 人工知能学会誌, Vol.25, No.2, pp.259-267(2010).

[大川内 10] 大川内 祐介, 平嶋 宗: “派生問題の自動生成之 その実験的評価”，教育システム情報学会第 35 回全国大会講 演論文集, pp.517-518(2010).

[Scheiter 02] K. Scheiter, P. Gerjets: The Impact of Problem Order: Sequencing Problems as a Strategy for Improving One Performance, Proc. of the 24th Annual Conference of the Cognitive Science Society, pp.798-803(2002).

[菅沼 05] 菅沼 昭, 峯 恒憲, 正代 隆義 : “学生の理解度と問 題の難易度を動的に評価する練習問題自動生成システム”, 情 報処理学会論文誌, Vol.46, No.7, pp.1810-1818(2005).

[武智 12] 武智俊平, 大川内祐介, 平嶋宗, "学習者に個別対 応可能な漸進的問題演習の実現", JSiSE2012 学生研究発表 会, pp.168-169, (2012).

[東本 08] 東本 崇仁, 堀口 知也, 平嶋 宗: “シミュレーショ ンに基づく学習環境における漸進的な知識獲得支援のための マイクロワールドグラフ”，電子情報通信学会論文誌，Vol. J91-D, No. 2, pp. 303-313 (2008).

[上野 09] 上野拓也, 堀口 知也, 平嶋 宗: “マイクロワール ドグラフを用いた派生問題の対話的自動生成システム”, 人工 知能学会第 23 回全国大会(2009).

〔担当委員 : 山川 宏〕

2012 年 2 月 3 日 受理

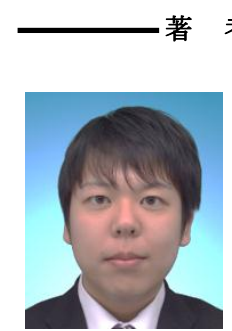

紹 介

ステムズ・ウエストに勤務。

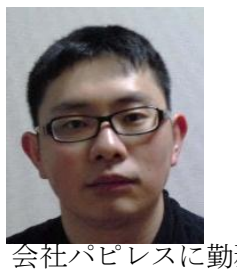

上野 拓也

2008 年広島大学工学部卒業. 2010 年同大学 大学院工学研究科博士課程前期修了. マイ クロワールドグラフを利用した派生問題自 動生成システムの開発に従事. 現在, 株式 務.

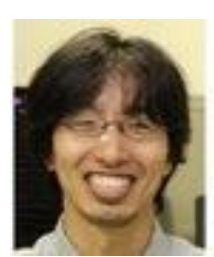

平嶋 宗（正会員）

1986 年大阪大学工学部卒業, 1991 年同大大 学院博士課程了, 同年同大産業科学研究所 助手. 同講師, 九州工業大学情報工学部助 教授を経て, 2004 年より広島大学大学院工 学研究科教授. 人間を系に含んだ計算機シ ステムの高度化に関する研究に従事. 工学博士. 